\title{
The Relationship between Management Responsibility, Service Quality Accountability, and the Effectiveness of the Quality Assurance System at Jabal Ghafur University
}

\author{
Boihaki $^{1}$, Teuku Isnaini' ${ }^{1}$, Cut Yusnidar ${ }^{1}$, Fuad $^{2}$ \\ ${ }^{1}$ Jabal Ghafur Univerisity, Sigli, Indonesia \\ ${ }^{2}$ Al-Hilal Collage, Sigli, Indonesia \\ boihaki@unigha.ac.id
}

\begin{abstract}
The objectives of this research were to describe the effectiveness of quality assurance system at Jabal Ghafur University and to find the relationship between management responsibility, service quality accountability, and team performance with the effectiveness of quality assurance system at Jabal Ghafur University. This current research employed qualitative approach, $x$ post facto research category of correlative description. The population of this research was permanent lecturers at Jabal Ghafur University. As many as 150 samples were taken from the population by using proportional cluster sampling technique. The data were collected by using questionnaire and were further analyzed by employing Structural Equation modeling (SEM) on Partial Least Square (PLS) software. The results of the research showed that (1) the effectiveness of quality assurance system, service quality accountability, and management responsibility fell into the average category of good, (2) the higher team performance was not followed by the more effective quality assurance system.
\end{abstract}

Keywords

effectiveness of quality

assurance system; management responsibility; service quality

\section{Introduction}

Higher education needs to control the quality of activities carried out at each stage in its sustainability which includes input, process, output and stakeholder satisfaction through the application of good university governance, namely mastery which includes; Management Responsibility, Service Quality Accountability, Quality Culture, Organizational Learning, and Team Performance. In general terms, quality assurance, the term that earned an important place in higher education institutions in recent years, can be defined as systematically monitoring and assessing various dimensions of a project/service/institution in order to determine whether it meets the quality standards (Özer et al., 2010).

According to Alzhrani, Alotibie, \& Abdulaziz (2016) Quality has a variety of definitions and a broad concept. For some, quality is linked to the meaning of superiority and excellence, and to others quality is an assurance that there are fewer services or products with defects. Quality is otherwise linked to product features. According to Nadim and Al-Hinai (2016), quality in education is a very vital issue because HEIs are accountable to several stakeholders such as students, society and others. Also, the quality of he is one of the most significant aspects of the creation of knowledge, human resource development and social force for any country. 
So it can be concluded that what is meant by a higher education quality assurance system is quality management that guarantees satisfaction or confidence to stakeholders that higher education quality requirements will be met, through the process of determining and fulfilling the quality of higher education management in accordance with established standards and procedures. Whereas what is meant by the quality of management of tertiary institutions is the suitability of the tertiary education management process with established standards and procedures. Based on the various perspectives on quality assurance described above, this study establishes the approach used to measure the effectiveness of the quality assurance system is an internal process approach or management process in implementing a quality assurance system.

Measurement of the effectiveness of the quality assurance system in this study is the internal process approach using standard-setting process components, standard fulfilment processes and control processes. The components of the standard-setting process are translated into indicators which include, formulation of objectives, decision making. Components of the standard fulfilment process are broken down into indicators which include, leadership, standard fulfilment mechanisms, motivational strength, communication systems. Quality has been altered with the transition of time, modification of customer's needs and demands. But the vitality has more or less been progressed to resolve the issue, compliance to standards for customer satisfaction. With management routine getting complicated, attacks to managing quality in operational areas are becoming unmanageable (Mohammed Hasan, 2014).

Soetopo (2005) states that universities today are directed to fulfil the aspects of autonomy, transparency, accountability, quality assurance and quality improvement in order to remain trusted by the public. According to Sallis (1993) that a quality improvement program must involve all people who work in an institution. The improvement in educational quality strongly emphasizes the importance of the role of the school as an autonomous primary offender and the role of the principal in developing education (Musdiani, 2019). However, in Turkey, the processes from opening a higher education institution to launching programs are bound to strict regulations and under no condition, education can be provided unless approval from the relevant institutions is received. In such a higher education system that requires a large bureaucratic structure, implementing accreditation on top of all other arrangements will only increase the higher education bureaucracy more (Özer, 2010).

Sallis (2003) states that culture change is a concept that aims to form an organizational culture that values quality and makes quality the orientation of all organizational components. The organizational culture required to be regenerated on a consistent basis to inspire employee evaluation. Employees are full of beneficial observation and pay attention to those administering the procedures that keep the business running. If employees have any concept on how to have better operations, they need to be aware of management courtesies to impart their ideas so we can utilize it (Mohammed Hasan, 2014). The purpose of this study was to find a picture of the effectiveness of the quality assurance system, service quality accountability, and management responsibility at Jabal Ghafur Sigli University.

\section{Review of Literature}

\subsection{Understanding of the Internal Quality Assurance System}

The internal quality assurance system is a systemic activity of higher education quality assurance in tertiary institutions by universities (internally driven), to oversee the 
implementation of tertiary education by universities on an ongoing basis (continuous improvement), as regulated by Article 50 paragraph (6) of the National Education System Law juncto Article 91 PP No, 19 of 2005 concerning SNP. In general it can be stated that what is meant by quality assurance is planning, implementation, control, and development of higher education quality standards consistently and continuously (continuous improvement / kaizen), so that stakeholders, both internal and external, obtain satisfaction.

Maintain and improve the quality of higher education on an ongoing basis, which is run by a college internally, to realize the vision, as well as to meet the needs of stakeholders through the organization of Higher Education Tridharma. Performance or achievements interpreted as an expression of the ability of labor based on the knowledge, attitudes, soft skill and motivation to produce something. Job performance is defined as an achievement of certain requirements which ultimately can be directly reflected in the output produced both in quantity and quality (Zahara, 2019). Achievement of quality assurance goals is carried out through SPMI, to then obtain accreditation through SPME by BAN-PT or an independent institution recognized by the Government. Thus, continuous improvement in the quality of higher education can be realized comprehensively through SPM-PT, as can be seen in the following figure.

\subsection{Accountability}

This principle is seen through management responsibility through effective supervision between managers, shareholders, boards commissioners and auditors equally. This is a form clarity of function, implementation, and organ accountability effective (Nyoman Tjager, et al, 2004). This principle is realized among others by preparing reports financial (financial statement) at the right time; develop audit and risk committees to support functions supervision by the board of commissioners; develop and formulate rerole and function of internal audit as a business partner strategic; keep contract management accountable and handle disputes; law enforcement through the system awards and sanctions; and using an external auditor who Professional. (Nyoman Tjager, et al, 2004).

\subsection{Responsibility}

The principle of responsibility is conformity or compliance in management the company towards the principles of sound corporate and statutory regulations in effect (Mas Achmad Daniri, 2008). The principle of responsibility is realized with the awareness that responsibility responsibility is a logical consequence of having authority, aware of it social responsibility, avoid abuse of power, being professional while upholding ethics in doing business, and creating and maintaining a healthy business environment. Other than that, this principle also contains principles that reflect management performance good company and recognize stakeholders and encourage collaboration which is active between the company and stakeholders to create prosperity. Also creates employment opportunities that are supported by financial health and cooperation between the company and stakeholders who really help the company's performance and actions socially responsible company (Ridwan Khairandy, 2009). Corporate social responsibility is defined as a business operation that is committed not only to increase company profits financially, but for regional socio-economic development in a holistic, institutionalized and sustainable manner (Saleh, 2019). In addition, the company fulfills its responsibilities to shareholders and stakeholders must comply with the law and current regulation. Also companies are required not only to comply with the Limited Liability Company Law but also to comply 
with the law other laws such as the Manpower Act, the Law Monopoly and Unfair Business Competition and Environmental Laws Life. (Ridwan Khairandy, 2009).

According to the Decree of the Minister of State-Owned Enterprises Number: KEP117/M-MBU/2002 that in addition to the four principles above, there is still one additional principle again, namely the principle of independence (Independence). This principle interpreted as a situation where the company is managed professionally without conflict of interest and influence / pressure from any party that is not in accordance with applicable laws and principles healthy corporation. Azhar Maksum said that the principle of independence more towards companies in the form of BUMN (Azhar Maksum, 2005). The main principles of corporate governance outlined above according to A. Sofyan Djalil can be translated into five main aspects. OECD arrange the principles of corporate governance which are grouped into category (Sofyan A. Djalil, 2000).

a. Shareholder rights.

b. Fair treatment for all shareholders.

c. The role of stakeholders in corporate governance.

d. Disclosure obligations and transparency.

e. The responsibilities of directors and commissioners.

Related to the regulation of good corporate governance in the legal framework nationally, Indonesia has been hit by an economic crisis around 1997/1998, while a movement towards reforming the conditions of the new corporate governance began in 1999 with the formation of the National Policy Committee Corporate Governance (KNKCG or NCCG) (Azhar Maksum, 2005). Formation of the National Committee Corporate Governance Policy through Decree Number: KEP- 10 / M.EJUIN / 08/1999 dated August 19, 1999. This decree was renewed by replacing membership through Decree No. KEP- 31 / M.EKUIN / 06/2000 concerning the establishment of a National Committee Regarding Corporate Governance Policy. National Committee on Policy Corporate Governance then changed to National Policy Committee Governance with the decision of KEP-49 / M.EKO / 11 / 2004.80 But it was a moment important that will determine the concept of corporate governance in travel Indonesia further only took place in 2001, namely by the formation of a good corporate governance guidelines (Indonesian Code) by the NCCG together business people (Mas Achmad Daniri, 2004).

\section{Research Methods}

This study uses a quantitative approach, the approach in this study is quantitative research that is research focused on the study of objective phenomena to be studied quantitatively (Musfiqon, 2012). This type of research is ex post facto research, namely research that aims to investigate the events that have occurred and then trace back to find out the factors that caused these events (Sugiyono 2012). The study population was all permanent lecturers at Jabal Ghafur University. The intended permanent lecturers are foundation lecturers and DPK lecturers at Jabal Ghafur University, as many as 150 people.

Sampling is done by proportional cluster sampling technique. The number of samples is 15 or around $9 \%$ to $10 \%$ of the total population. So that in this study took $10 \%$ of the total population by random (random), which is 15 people. Data collection uses one type of instrument, the questionnaire. The instruments in this study were tested and declared valid with a correlation coefficient (rxy)> 0.4 and declared reliable with an alpha coefficient> 0.9. Data analysis in this study uses the SEM (Structural Equation Modeling) model with the help of Partial Least Square (PLS) software. 


\section{Discussion}

Description of research data to find a picture of the effectiveness of the quality assurance system and other variables in this study. As for determining whether the description of the variables of this study has a very good category, a good category, a poor category, and a very poor category, the researcher uses the following criteria: (a) $1 \leq$ average $<1.5$ very poor categories; (b) $1.5 \leq$ average $<2.5$ fewer categories; (c) $2.5 \leq$ average $<3.5$ good categories; and (d) 3,5<average $\leq 4$ categories very well. The representations of the research data are as follows: (1) the effectiveness of the quality assurance system at Jabal Ghafur University shows good condition, lies in the range of 2.5 er average <3.5 with a scale value of 2.83 ; (2) accountability of service quality at Jabal Ghafur University shows good condition lies in the range of 2.5 er average $<3.5$ with a scale value of 3.1; and (3) management responsibility at Jabal Ghafur University shows good condition lies in the range of $2.5 \leq$ average $<3.5$ with a scale value of 2.87 .

While the results of the causal relationship between variables, the findings of a number of 20 hypotheses of this study after being tested turned out there were 8 hypotheses rejected and 12 hypotheses were accepted with a significant level of $5 \%$ or a 95\% confidence level. The accepted hypothesis is: (1) there is a significant direct relationship between management responsibility and service quality accountability at Jabal Ghafur University (correlation coefficient $0,5=0.501$, a significance level of $5 \%$ ), (2) there is an indirect significant relationship between responsibility management with the effectiveness of the quality assurance system at Jabal Ghafur University (coefficient of indirect relationships $\gamma=0.378$, a significance level of $5 \%$ ).

\subsection{Relationship between Responsibility and Effectiveness Quality Assurance System}

The results of data analysis show that it is not there is a significant direct relationship between responsibility management with the effectiveness of the quality assurance system. But the results of data analysis showed that there is an indirect relationship between management responsibility with system effectiveness quality assurance, through team performance. This shows that management responsibility cannot directly affect the effectiveness of the system quality assurance, but responsibility can only be affect team performance, which subsequently performance the team can influence the effectiveness of the guarantee system quality. The results of data analysis also showed that quality policy, organizational structure, and assessment management has a high validity in reflect management responsibility. That can be it is suspected that the university leadership in applying quality policy, organizational structure and implementing quality management assessment can build or fix the team's performance at the university. This is in line with opinion Sallis (1993) that quality management success good staff commitment and cooperation are needed. This opinion implies that effectiveness quality system is not solely the responsibility and senior or top management commitment but shared. There are data analysis results show that there is an indirect relationship between responsibility management with the effectiveness of the guarantee system quality, through quality culture. In other words, responsibility can build or enhance culture university quality so that quality culture can improve effectiveness of the quality assurance system. Thing it can be suspected that the leadership of the university is in implementing quality policies, structures or provisions and carrying out quality management assessment not can directly affect effectiveness quality assurance system. But in influencing the effectiveness of the quality assurance system is still on need to fix its quality culture and shape highperformance team. The statement in line with the statement of Usman (2006) which states 
that quality assurance is a responsibility team answer; Tampubolon (2001) statement of teamwork is a very effective strategy in an effort to improve the quality of higher education sustainable. Based on the description above, then it can be concluded that responsibility is not can influence directly on effectiveness quality assurance system, but through culture quality and team performance.

\subsection{Relationship between Service Quality Accountability with the effectiveness of the Quality Assurance System}

The results of data analysis show that it is not there is a significant direct relationship between accountability qualities of service with the effectiveness of the system quality assurance. But the results of data analysis showed that there is a relationship between quality accountability services with organizational learning. This means that improving the quality of services performed by university leaders cannot be impacted directly to the effectiveness of quality assurance, but improving the quality of these services can influence the learning of university organizations. This is in line with the opinion of Gronroos (1990) which states that the service quality includes quality of function by emphasizing how

a service is performed which consists of contact dimensions with consumers, attitudes and behaviors, internal relationships, appearance, ease of access. Based on this opinion it can be concluded that the quality of service can improve the effectiveness of the quality assurance system if attitude mentally, resource capabilities must be built through organizational learning and improve performance the team at the university. So that it can concluded that accountability for service quality cannot influence directly on the effectiveness of the quality assurance system, but it can directly affect organizational learning.

\section{Conclusion}

From the results of the study it can be concluded as follows: (1) the higher the responsibility of management, the quality assurance system is not followed by the effectiveness of higher education institutions, especially private universities; (2) the higher the management responsibility, the more effective the quality assurance system at Jabal Ghafur University is not followed; (3) the higher the quality of service accountability, the more effective the quality assurance system at Jabal Ghafur University is not followed.

\section{References}

Azhar Maksum, "Tinjauan Atas Good Corporate Governance di Indonesia", disampaikan pada Pidato Pengukuhan Jabatan Guru Besar Tetap dalam Bidang Ilmu Akutansi Manajemen pada Fakultas Ekonomi Universitas Sumatera Utara, Gelanggang Mahasiswa Kampus USU, 17 Desember 2005,

Alzhrani, K. M., Alotibie, B. A., \& Abdulaziz, A. (2016). Total Quality Management in Saudi Higher Education. International Journal of Computer Applications, 135(4), 612. https://doi.org/10.5120/ijca2016908245

Mohammed Hasan. In'airat, Total Quality Management in Higher Education: A Review, International Journal of Human Resource Studies ISSN 2162-3058 2014, Vol. 4, No. 3.

Musdiana, Mardhatillah and Khausar. (2019). Analysis the Role of Headmaster in Applying Quality of Education in Primary School Districts, Aceh Barat. Budapest 
International Research and Critics in Linguistics and Education (BirLE) Journal, 2735.

Musfiqon. 2012. Metodologi Penelitian Pendidikan.Prestasi Pustaka Raya.Jakarta

Nadim, Z. S., \& Al-Hinai, A. H. (2016). Critical Success Factors of TQM in Higher Education Institutions. International Journal of Applied Sciences and Management, 1(2). Retrieved from https://www.waljatcollege.edu.om/journal/archive-2016.html

Özer, M. (2010). Yükseköğretimde kalite güvencesi üzerine. Cumhuriyet Bilim Teknoloji.

Saleh, A., et al. (2019). Development of Banking CSR Model for Community Empowerment Slum Area in Medan City. Budapest International Research and Critics Institute-Journal (BIRCI-Journal), 39-50.

Sallis, E. (2003). Total Quality Management in Education. London: Kogan Page Education Management Series.

Soetopo, H. 2005, Keefektifan Organisasi Perguruan Tinggi dalam Penjaminan Mutu Pendidikan. Materi Pidato Pengukuhan Guru Besar. Malang: Universitas Negeri Malang.

Sugiyono (2012). Metode Penelitian Kuantitatif dan Kuwalitatif.Alfabeta. Bandung

I Nyoman Tjager, et al., Corporate Governance-Tantangan dan Kesempatan bagi Komuitas Bisnis Indonesia, (Jakarta: PT. Prenhallindo, 2004).

Sofyan Djalil, "Good Corporate Governance", Disampaikan pada Seminar Good Corporate Governance di Universitas Sumatera Utara pada tanggal 26 Juni 2000.

Zahara, S. and Wijaya, C. (2019). The Relationship of Self-Concept and Work Satisfaction with Teachers' Performance of Islamic Elementary School in Tebing Tinggi, Indonesia. Budapest International Research and Critics in Linguistics and Education (BirLE) Journal, 123-136. 